\title{
Front Matter: Volume 11168
}

, "Front Matter: Volume 11168," Proc. SPIE 11168, Advanced Manufacturing Technologies for Micro- and Nanosystems in Security and Defence II, 1116801 (15 November 2019); doi: 10.1117/12.2554469 


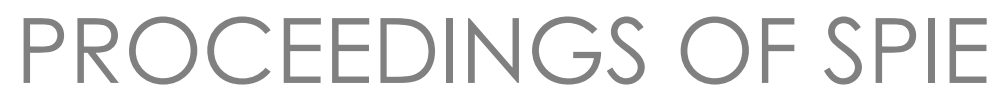

\title{
Advanced Manufacturing Technologies for Micro- and Nanosystems in Security and Defence II
}

\author{
Andrea Camposeo \\ Yuris Dzenis \\ Maria Farsari \\ Luana Persano \\ Editors \\ 9-10 September 2019 \\ Strasbourg, France \\ Sponsored by \\ SPIE \\ Cooperating Organisations \\ European Optical Society \\ Cranfield University (United Kingdom) \\ Published by \\ SPIE
}

Volume 11168 
The papers in this volume were part of the technical conference cited on the cover and title page. Papers were selected and subject to review by the editors and conference program committee. Some conference presentations may not be available for publication. Additional papers and presentation recordings may be available online in the SPIE Digital Library at SPIEDigitalLibrary.org.

The papers reflect the work and thoughts of the authors and are published herein as submitted. The publisher is not responsible for the validity of the information or for any outcomes resulting from reliance thereon.

Please use the following format to cite material from these proceedings:

Author(s), "Title of Paper," in Advanced Manufacturing Technologies for Micro- and Nanosystems in Security and Defence II, edited by Andrea Camposeo, Yuris Dzenis, Maria Farsari, Luana Persano, Proceedings of SPIE Vol. 11168 (SPIE, Bellingham, WA, 2019) Seven-digit Article CID Number.

ISSN: 0277-786X

ISSN: 1996-756X (electronic)

ISBN: 9781510630390

ISBN: 9781510630406 (electronic)

Published by

SPIE

P.O. Box 10, Bellingham, Washington 98227-0010 USA

Telephone +1 3606763290 (Pacific Time) · Fax +1 3606471445

SPIE.org

Copyright (c) 2019, Society of Photo-Optical Instrumentation Engineers.

Copying of material in this book for internal or personal use, or for the internal or personal use of specific clients, beyond the fair use provisions granted by the U.S. Copyright Law is authorized by SPIE subject to payment of copying fees. The Transactional Reporting Service base fee for this volume is $\$ 21.00$ per article (or portion thereof), which should be paid directly to the Copyright Clearance Center (CCC), 222 Rosewood Drive, Danvers, MA 01923. Payment may also be made electronically through CCC Online at copyright.com. Other copying for republication, resale, advertising or promotion, or any form of systematic or multiple reproduction of any material in this book is prohibited except with permission in writing from the publisher. The CCC fee code is 0277$786 \mathrm{X} / 19 / \$ 21.00$.

Printed in the United States of America by Curran Associates, Inc., under license from SPIE.

Publication of record for individual papers is online in the SPIE Digital Library.

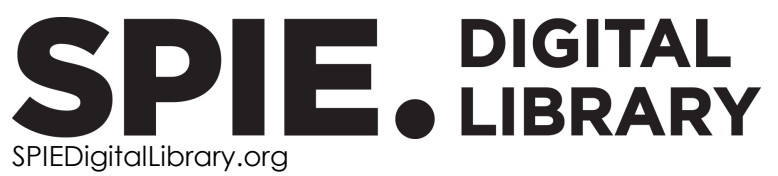

Paper Numbering: Proceedings of SPIE follow an e-First publication model. A unique citation identifier (CID) number is assigned to each article at the time of publication. Utilization of CIDs allows articles to be fully citable as soon as they are published online, and connects the same identifier to all online and print versions of the publication. SPIE uses a seven-digit CID article numbering system structured as follows:

- The first five digits correspond to the SPIE volume number.

- The last two digits indicate publication order within the volume using a Base 36 numbering system employing both numerals and letters. These two-number sets start with $00,01,02,03,04$, 05, 06, 07, 08, 09, OA, OB ... 0Z, followed by 10-1Z, 20-2Z, etc. The CID Number appears on each page of the manuscript. 


\title{
Contents
}

\author{
$\checkmark \quad$ Authors \\ vii Conference Committee \\ ix Introduction
}

ADVANCED NANOFABRICATION

$1116802 \quad$ Ultrashort ring-Airy laser beams for advanced materials engineering (Invited Paper) [11168-1]

1116805 DNA-based nanofabrication for low-cost, high-resolution patterning (Invited Paper) [1 $1168-4]$

SMART STRUCTURES AND INTERFACES

$1116809 \quad$ Figuring of fused silica optical surface with thin parts by plasma chemical vaporization machining [1 $11168-8]$ 
Proc. of SPIE Vol. $111681116801-4$

Downloaded From: https://www.spiedigitallibrary.org/conference-proceedings-of-spie on 26 Apr 2023 Terms of Use: https://www.spiedigitallibrary.org/terms-of-use 


\section{Authors}

Numbers in the index correspond to the last two digits of the seven-digit citation identifier (CID) article numbering system used in Proceedings of SPIE. The first five digits reflect the volume number. Base 36 numbering is employed for the last two digits and indicates the order of articles within the volume. Numbers start with 00, 01, 02, 03, 04, 05, 06, 07, 08, 09, 0A, 0B...0Z, followed by 10-12, 20-2Z, etc.

Farsari, Maria, 02

Fedorov, Vladimir Yu., 02

Hui, Liwei, 05

Liu, Haitao, 05

Manousidaki, Maria, 02

Mori, Yuzo, 09

Papazoglou, Dimitrios G., 02

Sano, Yasuhisa, 09

Takino, Hideo, 09

Tzortzakis, Stylianos, 02

Yamamura, Kazuya, 09 
Proc. of SPIE Vol. $111681116801-6$

Downloaded From: https://www.spiedigitallibrary.org/conference-proceedings-of-spie on 26 Apr 2023 Terms of Use: https://www.spiedigitallibrary.org/terms-of-use 


\section{Conference Committee}

Symposium Chairs

Ric Schleijpen, TNO Defence, Security and Safety (Netherlands)

Karin U. Stein, Fraunhofer-Institut für Optronik, Systemtechnik und Bildauswertung (Germany)

Symposium Co-chair

Catherine Barrat, HGH Systèmes Infrarouges (France)

Conference Chairs

Andrea Camposeo, Istituto Nanoscienze, CNR (Italy)

Yuris Dzenis, University of Nebraska-Lincoln (United States)

Maria Farsari, Foundation for Research and Technology-Hellas (Greece)

Luana Persano, Istituto Nanoscienze-CNR (Italy)

Conference Programme Committee

Tommaso Baldacchini, Newport Corporation (United States)

Lynda E. Busse, U.S. Naval Research Laboratory (United States)

John T. Fourkas, University of Maryland, College Park (United States)

Jesper Glückstad, Technical University of Denmark (Denmark)

Andreas Heinrich, Hochschule Aalen - Technik und Wirtschaft (Germany)

Natalia Vladimirovna Kamanina, S.I. Vavilov State Optical Institute

(Russian Federation)

Eunkyoung Kim, Yonsei University (Korea, Republic of)

Norihisa Kobayashi, Chiba University (Japan)

Beata Luszczynska, Lodz University of Technology (Poland)

Andreas Ostendorf, Ruhr-Universität Bochum (Germany)

Alberto Piqué, U.S. Naval Research Laboratory (United States)

Dario Pisignano, Università di Pisa (Italy)

Bastian E. Rapp, Karlsruher Institut für Technologie (Germany)

Haizheng Zhong, Beijing Institute of Technology (China)

Session Chairs

1 Advanced Nanofabrication

Andrea Camposeo, Istituto Nanoscienze (Italy)

2 Smart Structures and Interfaces

Sara Cavaliere, Institut Charles Gerhardt Montpellier (France) 
3 Additive Manufacturing for Actuation Systems

Lynda E. Busse, U.S. Naval Research Laboratory (United States)

$43 \mathrm{D}$ and 4D Printing

Guy Schlatter, Institut de Chimie et Procédés pour l'Energie, I'Environnement et la Santé (France) 


\section{Introduction}

The second edition of the conference Advanced Manufacturing Technologies for Micro- and Nanosystems in Security and Defence was held in Strasbourg, France, 9-10 September 2019, within the framework of SPIE Security + Defence 2019. The conference aims to establish a platform for the most innovative and advanced manufacturing technologies, which can have an impact on the fabrication of photonic and optoelectronic devices for security and defense applications. In this context, there is an increasing interest in novel manufacturing technologies which might enable the fabrication and assembly of devices by autonomous systems, capable of operating in harsh and hostile environments, possibly by remote control. The emerging $3 D$ printing technologies and self-assembly nanotechnologies in combination with smart and functional materials can provide interesting new routes towards self-assembling, self-repairing and self-powering devices for defence and security.

The conference's two days of technical sessions gave us an updated overview of the state-of-the-art of the most advanced manufacturing technologies for photonic and optoelectronic devices, which included high resolution 3D printing technologies, electrospinning, additive manufacturing of optical components, 4dimensional printing, surface patterning and treatment, solid state lasers and novel application of electrospun fibers.

This volume highlights the papers presented at the conference, which include the use of ultrashort ring-airy laser beams for the fabrication of 3D structures on large areas with high resolution by using multiphoton polymerization and the treatment of optical surfaces by plasma chemical vaporization machining. In addition, DNAbased nanofabrication approaches are reviewed and demonstrated to be a valuable tool for high resolution pattering. 
The conference chairs acknowledge all authors for their contributions to the symposium. Special thanks go to the members of the Program Committee for their valuable contribution and to the invited speakers for their exciting and inspiring presentations. We also thank the SPIE staff for their efforts and outstanding service in preparing the conference and publishing the proceedings.

\section{Andrea Camposeo Luana Persano}

